\title{
Powerful birds. The Eurasian jay (Garrulus glandarius) and the osprey (Pandion haliaetus) in hunter-gatherer burials at Zvejnieki, northern Latvia and Yuzhniy Oleniy Ostrov, northwestern Russia
}

\section{KEY WORDS \\ Prehistory, \\ bird bones, \\ wing symbolism, \\ burial practices, \\ hunter-gatherers, \\ Oleniy Ostrov, \\ Zvejnieki.}

MOTS CLÉS

Préhistoire,

ossements d'oiseaux,

symbolisme,

pratiques funéraires,

Oleniy Ostrov, Zvejnieki.

\author{
Kristiina MANNERMAA \\ Faculty of Arts, Department of Philosophy, History, Culture and Art Studies, \\ P.O. Box 59, 00014 University of Helsinki (Finland) \\ kristiina.mannermaa@helsinki.fi
}

\begin{abstract}
Mannermaa K. 2013. - Powerful birds. The Eurasian jay (Garrulus glandarius) and the osprey (Pandion haliaetus) in hunter-gatherer burials at Zvejnieki, northern Latvia and Yuzhniy Oleniy Ostrov, northwestern Russia. Anthropozoologica 48 (2): 189-205. http://dx.doi.org/10.5252/ az2013n2a1
\end{abstract}

\begin{abstract}
Recent archaeological studies reveal the importance of birds in prehistoric NorthEuropean hunter-fisher-gatherer burial practices. In this article I describe two examples of bird species at prehistoric hunter-gatherer burials: the Eurasian jay (Garrulus glandarius) at the Middle Neolithic Zvejnieki site in northern Latvia, and the osprey (Pandion haliaetus) at the Late Mesolithic Yuzhniy Oleniy Ostrov site in western Russia. I suggest that the bone finds and their archaeological contexts indicate a prehistoric ideology that can be interpreted as representing totemism and shamanism. The wing bones had a specific function and meaning, probably connected to protection, transformation or transport. The deposition of osprey legs may indicate that the power of this bird was particularly appreciated and re-mobilized in the burial.
\end{abstract}

\section{RÉSUMÉ}

Le pouvoir des oiseaux: le geai des chênes (Garrulus glandarius) et le balbuzard pêcheur (Pandion haliaetus) dans les tombes de chasseurs cueilleurs de Zvejnieki, (Lettonie du nord) et Yuzhniy Oleniy Ostrov (Russie du nord-ouest).

Les récentes recherches archéologiques ont révélé la signification des oiseaux dans les pratiques funéraires des communautés de chasseurs, cueilleurs, pêcheurs préhistoriques en Europe du nord. Cet article présente deux oiseaux qui apparaissent dans des tombes de communautés de chasseurs : le geai (Garrulus glandarius), dans les tombes du Néolithique moyen de Zvejniek situé en Lettonie du nord, et le balbuzard (Pandion haliaetus) dans les tombes mésolithiques d'Yuzhniy Oleniy Ostrov situé en Russie du nord-ouest. Je suggère dans mon article que les os de geai et de balbuzard pourraient être interprétés comme représentant un univers totémiste et chamaniste. Les os de l'aile du geai avaient une signification et une fonction particulières dans les rituels funéraires; peut-être celles de protéger le défunt et de l'aider à atteindre l'autre monde. Symbolisant peut-être une force singulière pour les populations de la région de la Carélie, les os des pattes du balbuzard, placés dans la tombe auraient peut-être permis l'utilisation de cette force après la mort. 


\section{INTRODUCTION}

Animal bones are commonly found in prehistoric hunter-gatherers graves, such as the wild reindeer (Rangifer tarandus) and the Eurasian beaver (Castor fiber), at the Late Mesolithic Yuzhniy Oleniy Ostrov site in western Russia, and the red deer (Cervus elaphus) at the Late Mesolithic Skateholm in Sweden and Vedbæk in Denmark (Albrethsen \& Brinch Petersen 1976; Larsson 1989). It is notable, however, that scholars have mostly studied and interpreted mammal remains, whereas fish and bird bones have seldom been studied (see e.g., Jonsson 1986). This has been the case, for example, at the famous Late Mesolithic cemeteries Yuzhniy Oleniy Ostrov and Popovo in Karelia, northwestern Russia, and at the multi-period cemetery of Zvejnieki, in northern Latvia. Mammals from the graves were identified and published soon after excavations (Gurina 1956, Oshibkina 1982; Zagorskis 1987, 2004; see also Zagorska \& Lóugas 2000). Bird bones from Zvejnieki were analysed and published in 2006 (Mannermaa 2006) and bird bones from Yuzhniy Oleniy Ostrov in 2007 (Mannermaa et al. 2008). As the bird bones were not included in the original osteological analysis, they have also been excluded from archaeological interpretations.

Despite the fact that systematical analyses of bird remains from burials only started recently, archaeological studies in northern Europe have already revealed the importance of birds in prehistoric burial practices. A famous and often cited archaeological find is the grave from the Late Mesolithic Vedbæk Bøgebakken site in Denmark, containing the remains of a young woman with a new-born baby, the latter buried on a whooper swan wing (Albrethsen \& Brinch Petersen 1976). Bird bones were widely used in burial practices at Middle Neolithic cemeteries in Gotland and Öland, Sweden, and at the Middle Neolithic Tamula in southern Estonia (Janzon 1974; Mannermaa 2008a). The ritual or symbolic significance of different bird species for prehistoric cultures is well known for more recent periods, for example from Ancient Egypt and Iron Age Scandinavia (Sten \& Vretemark 1988, von den Driesch et al.
2005), but there are also several archaeological indications from Stone Age hunter-fisher-gatherer cultures. The earliest evidence of eagle worship in northern Europe comes from the Early Iron Age site of Ust' Poluisk in northwestern Siberia (Potapova \& Panteleyev 1999). One of the most impressive examples of the Stone Age bird cult is found in eastern Karelia, Russia where large swan figures have been carved into the Precambrian bedrock on the shores of Lake Onega (e.g., Lahelma 2012).

In this article I describe two examples of bird species at prehistoric hunter-gatherer burials: the Eurasian jay (Garrulus glandarius) at Zvejnieki, and the osprey (Pandion haliaetus) at Yuzhniy Oleniy Ostrov (Fig. 1), already briefly discussed by Mannermaa (2008a) and Mannermaa et al. (2008). The objectives of this study are to describe these burials and advance interpretations for the roles of birds in burial practices. The physical qualities and behaviour of these particular species provide insights into the ideological reasons for choosing these birds. The role of the osprey and the jay in prehistoric ideology and burial practices are appraised through analogies with known huntergatherer cultures in Fennoscandia and Siberia. These exceptionally rich ethnographic data were collected from various circumpolar cultures and tribes during the $19^{\text {th }}$ and $20^{\text {th }}$ centuries. Despite the controversial debate concerning the use of ethnographic data for interpreting prehistoric societies (e.g., Wylie 1985; Fahlander 2004), these data nevertheless provide an irreplaceable means for interpreting archaeological material evidence (see, e.g., Zvelebil \& Jordan 1999, Jordan 2004).

Multiple graves with osprey bones at Yuzhniy Oleniy Ostrov have been dated to the Late Mesolithic, c. 6200 cal BC (Price \& Jacobs 1990). The graves with jay bones at Zvejnieki have been dated to the Middle Neolithic period, c. 4300$3800 \mathrm{cal} \mathrm{BC}$ (Zagorska 1997). According to the animal osteological analysis carried out by Dr. Lembi Lóugas (2006), the Middle Neolithic groups at Zvejnieki based their subsistence on hunting, fishing and gathering. In central and southern Europe the term "Neolithic" means a gradual change to agriculture as the main form 

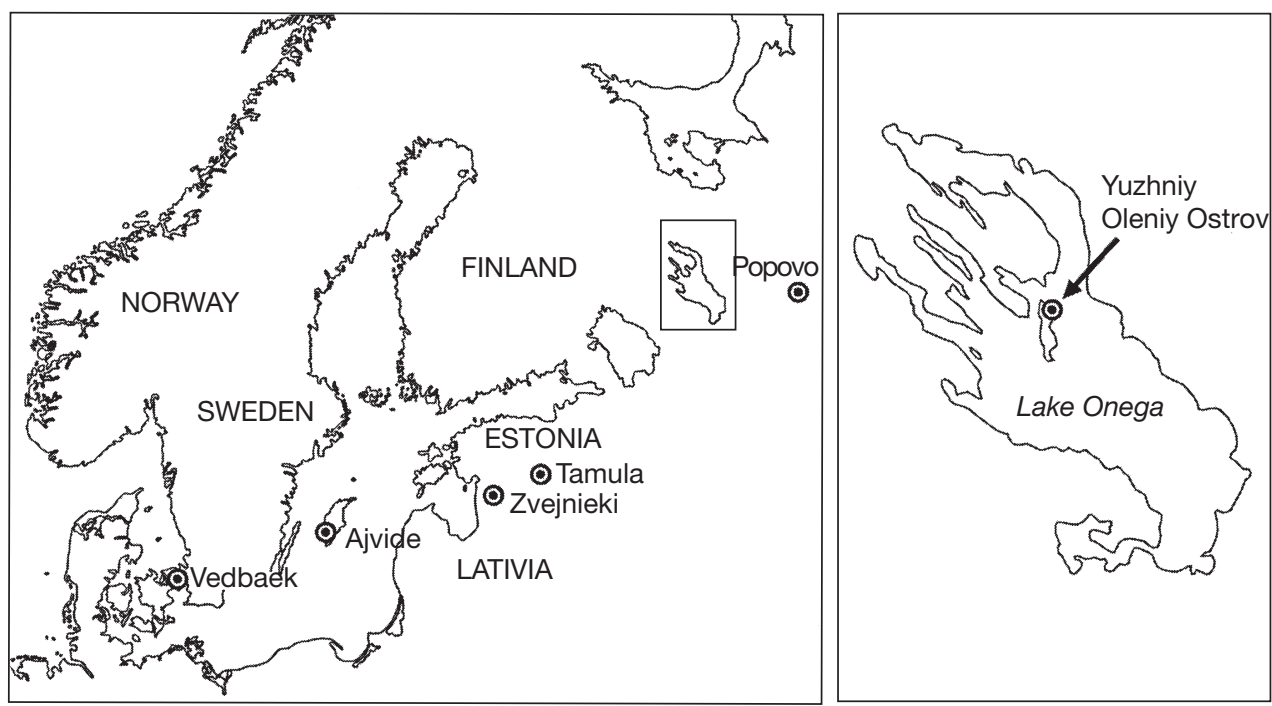

FIG. 1. - Location of cemeteries Zvejnieki in northern Latvia, Yuzhniy Oleniy Ostrov in northwestern Russia and other European burial sites mentioned in the text.

of subsistence, while the Neolithic in northern Fennoscandia and the Baltic countries is still dominated by hunter-gatherer groups. Here the term designates groups who produced ceramics but did not necessarily rely on an economy based on animal husbandry and agriculture. All the graves discussed in this article belong to non-farming societies with livelihoods and cultural traditions based on the exploitation of resources from forests, lakes and rivers.

\section{INTERPRETING ANIMAL REMAINS IN BURIALS}

Material remains from prehistoric people yield evidence for the different pragmatic and ideological roles of animals (e.g., Carpelan 1975; Ryan \& Crabtree 1995; Jones 1998; Jones O’Day et al. 2004). Unmodified and modified animal bones, various ornaments, and features such as body position or body treatment in graves represent burial practices and may reflect the ideology of the dead individual and/or those who buried him or her. A comprehensive approach is required to understand the grave entity and diverse burial practices (e.g., Nilsson Stutz 2009, Price et al. 2007, Losey et al. 2011). Mortuary activities connected to animal remains can be interpreted, for example; as projecting ideological aspects of death or the afterlife (for example food for the journey); as the passing of the body to another world after death; creating the identity of a place and landscape and reflecting social hierarchy (Jaanits 1961: 65; Larsson 1989; Jones 1998).

Loose animal bones in graves are frequently interpreted as the remains of meals intended for the dead or for the spirits (Larsson 1989, 1990; Burenhult 1997: 60). The meals may have taken place at the funeral site or in some other location, and only parts or symbols of the animals were brought to and placed in the grave. Ritual eating was a highly regulated activity, and among many known cultures it had a pragmatic intention: by eating a specific part of a special animal, the quality or power of that animal was re-mobilized.

A variety of animal species provided food for daily and ritual uses, but animals definitely had many other roles as well. The many ideological or practical meanings of animals among prehis- 


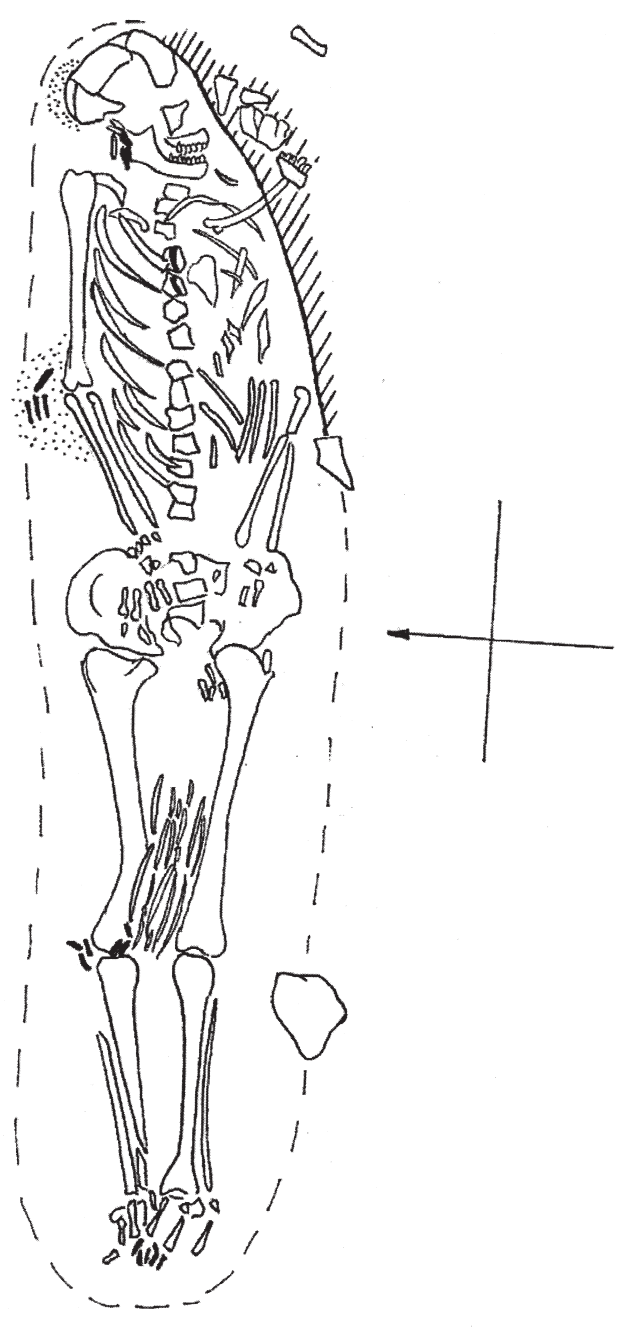

FIG. 2. - The Middle Neolithic grave 164 of an adult male at Zvejnieki, northern Latvia.

toric people are supported by ethnographic data gathered from recent hunter-gatherer-pastoral cultures (e.g., Okladnikov 1950; Karsten 1955; Napolskikh 1992). For example, in the Saami religion, some animals were perceived as guardian spirits (Karsten 1955; Hultkrantz 1987; Schanche 2000). According to Audhild Schanche (2000: 299), the animal bones in Saami graves and offering places may represent the dead animal's spirit. Bones hold a metaphorical relation to power and the spirit of the animal. By putting the bones of a spirit animal in a grave, its power accompanied the dead person (Schanche 2000: 296).

In the past, humans engaged in a deep cosmological relationship with animals. Anthropologists describe three approaches of engaging with the natural world among hunter-gatherers: animism, totemism and shamanism. Although these concepts are significant tools for understanding contemporary and prehistoric huntergatherer societies, it has to be noted that they are pragmatic and represent a wide variety of cultural systems. Ingold (2000: 112) underlines that totemism is not an explicit system to which people relate, but rather an orientation deeply embedded in everyday practice. The totem animal is one that has been recognized as a person and a member of a group or clan, and it can also be the spiritual forefather of the clan (see for example Ingold 1986; Harvey 2005: 164-168). The use of objects depicting totem animals in dress decoration is common practice among historical hunter-gatherer societies in Siberia, where strong symbolic meaning is attached to garments. The most helpful animals were depicted in shaman dresses and headgear among the circumpolar tribes (Prokofyeva 1963). For example, a Yakut shaman in Altai wore a costume that resembled a golden eagle (Lönnquist 1986: 84; Siikala 2002: 44).

Archaeological research into prehistoric huntergatherer burials in Northern Europe indicates that the dead were often buried with costumes decorated with pendants and other artefacts. Parts of important animals were fastened to these burial costumes as decorations and symbols, talismans or other magical objects (Gurina 1956, Larsson 2006). These costumes closely resemble those from recent hunter-gatherer-pastoral cultures. The original significance of the term "shaman" is a seer or a prophet, "a person who knows". The term and the concept refer to a set of universal but multifold ideological, even religious systems (e.g., Price 2001, Lewis-Williams 2003). In the following paragraphs I will briefly present how shamanism has been understood here and describe some central concepts which may enhance our understanding and interpretation 
of the ideological roles of animals and birds in particular.

The important elements of shamanism, for example, among the Saami, include the idea of powerful animals, used by the shaman as helpers or helping spirits when altering states of consciousness. The act of altering states of consciousness or changing between different worlds is a central component of shamanism, and has been subsumed into the early academic definitions (e.g., Eliade 1964, Price 2001). A shaman is able to use supernatural potency in order to heal, foretell and see things which cannot be perceived by others. But, he or she requires the assistance of animal-helpers and other spirits for empowerment in order to reach a range of altered states of consciousness. The visual, aural and somatic experiences often involved in these actions can be produced by different kinds of equipment, such as instruments, magical objects as well as natural phenomena from nature and the landscape. The drum is the most important instrument for a shaman in the Uralic world (e.g., Schefferus 1674/1963, Price 2001).

Marek Zvelebil (1997) suggested earlier that prehistoric shamanism could be seen in the burial practices at Yuzhniy Oleniy Ostrov. Historians of religion have also argued for the Stone Age roots of shamanism among the Fenno-Ugric people (Siikala 1981). A shamanistic ideology model has been convincingly used for interpreting rock art, for example in northern Fennoscandia (e.g., Lahelma 2005; 2008), but the difficulty in identifying shamanism in world-wide archaeological contexts has also been debated (e.g., Günther 2009, VanPool 2009).

Animal bones in direct association with human remains can often be interpreted as grave goods. This is especially true when animal bones bear evidence of anthropogenic modifications (e.g., artefacts such as pendants, hunting weapons, tools etc.). However, sometimes unmodified animal bones at graves turn out to be of different ages to those of the human skeleton (Mannermaa et al. 2007). For example, radiocarbon dates of several animal bones (from the Eurasian beaver, the wels catfish Silurus glanis and the wild boar Sus scrofa) in a double grave 316-317 at Zvejnieki clearly yielded older dates than those of the human skeletons (Larsson 2010). These animal bones ended up in the grave during the filling - the soil was taken from an older settlement site (Nilsson Stutz et al. 2008). The use of soil from the settlements of ancestors may indicate ancestor cults and the need to retain contact with dead members of the society. In order to avoid misinterpretations of animal bones it is important to establish that all animal bones found in graves were really meant as grave goods. The methods of estimating this include, e.g., contextual and taphonomic studies and radiocarbon dating.

\section{THE JAY AT ZVEJNIEKI}

\section{THE SITE}

The Zvejnieki archaeological complex, a former island, lies on the east side of Lake Burtnieks in northern Latvia (Fig. 1). The island is a flat longitudinal hill consisting of glaciofluvial pebbles and gravel. It was situated in the middle of the former Lake Burtnieks, which was significantly larger than today (Eberhards 2006). The site was excavated in the 1960s and 1970s by Francis Zagorskis (1987; 2004), and in 2005 and 2006 by Ilga Zagorska and Lars Larsson (Larsson \& Zagorska 2006; Nilsson Stutz et al. 2008; Larsson 2010). A total of 329 burials dating from the Middle Mesolithic to the Late Neolithic (c. 9000-3500 BP or 8300-1800 cal BC) have been excavated in the area. In addition to the cemetery, two settlement phases have been investigated (Zagorska 2006).

\section{JAYS IN GRAVES}

Almost forty unmodified carpometacarpal jay bones and three wing phalanges were found in the soil above the skeleton of an adult man in grave 164 (Fig. 2). The minimum number of individual jays in this grave is 17 (Mannermaa 2006). The man was placed on his back with his head facing east. Twenty of the wing bones were found around the chest; one between the left arm and vertebral column, twelve by the right elbow, three by the right knee and one near the 


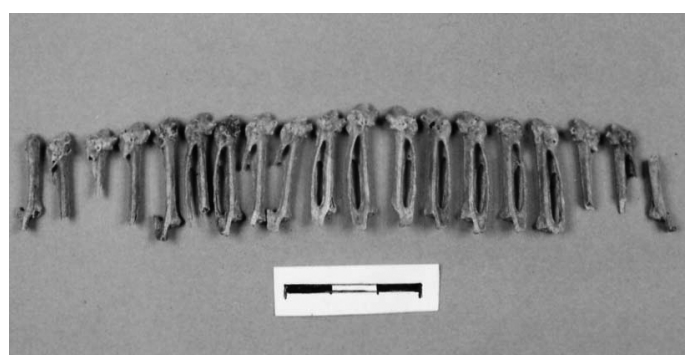

FIG. 3. - Twelve carpometacarpi (distal wing bones) of the Eurasian jay (Garrulus glandarius) were found by the right elbow of the deceased in Middle Neolithic grave 164 at Zvejnieki, northern Latvia. Photo Haralds Birznieks.

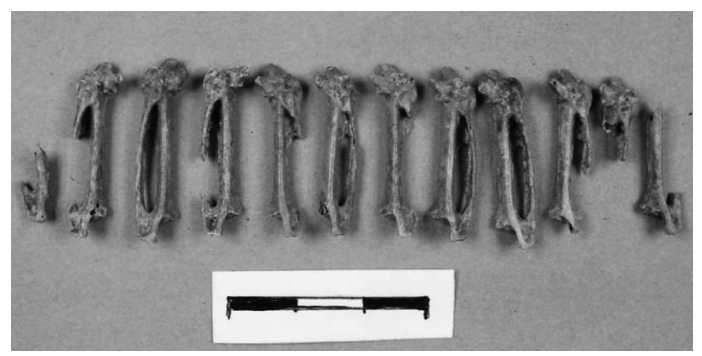

FIG. 4. - Twenty carpometacarpi (distal wing bones) of the Eurasian jay (Garrulus glandarius) were found at the chest, one between the left arm and vertebral column of the deceased in Middle Neolithic grave 164 at Zvejnieki, Photo Haralds Birznieks.

feet (Zagorskis 2004) (Figs 3; 4). Tooth pendants and red ochre occurred together with twelve jay carpometacarpal bones by the right elbow. One jay bone was found in the same position near the left arm, with two tooth pendants. The man wore a head ornament with seven tooth pendants (Zagorska \& Lóugas 2000:233). The teeth were from the red deer, the otter (Lutra lutra), the dog (Canis familiaris), the aurochs (Bos primigenus), the European elk (Alces alces) and the wild boar (Lóugas 2006: 84). Sixteen bone spearheads were put between his legs and a partial spearhead over the left side of the chest (Zagorskis 2004).

It is not possible to conclude by looking at the bird bones whether they were placed in the burial as loose bones or whether they still had feathers attached to them. However, the feathers could well have been attached to the bones because, on this part of the wing, the feathers are a deep blue (primary

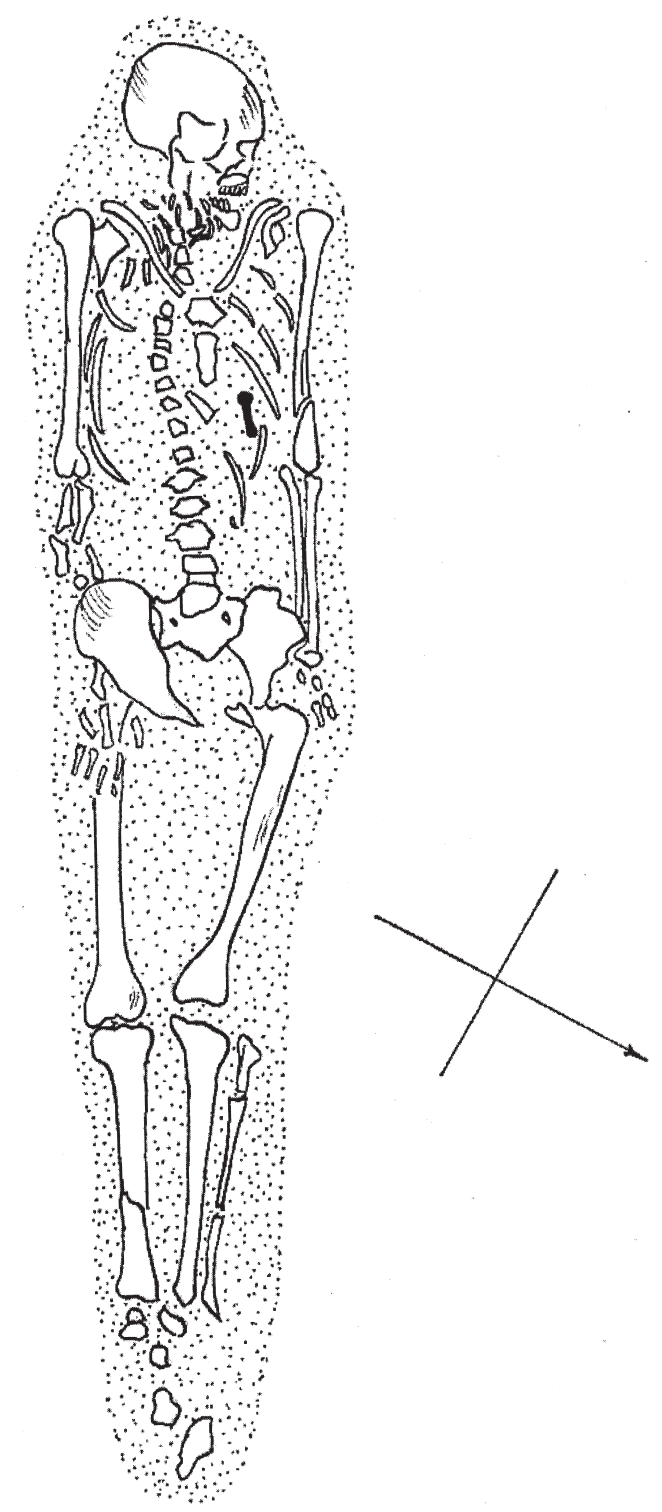

FIG. 5. - The Middle Neolithic grave 165 of an adult male at Zvejnieki, northern Latvia.

feathers). I believe that the carpometacarpal bones in burial 164 were the remains of blue wings from at least seventeen jay individuals that were used to decorate the burial costume. The jay bones were found in the soil above the skeleton which indicates that the dress was made of thick material, perhaps 


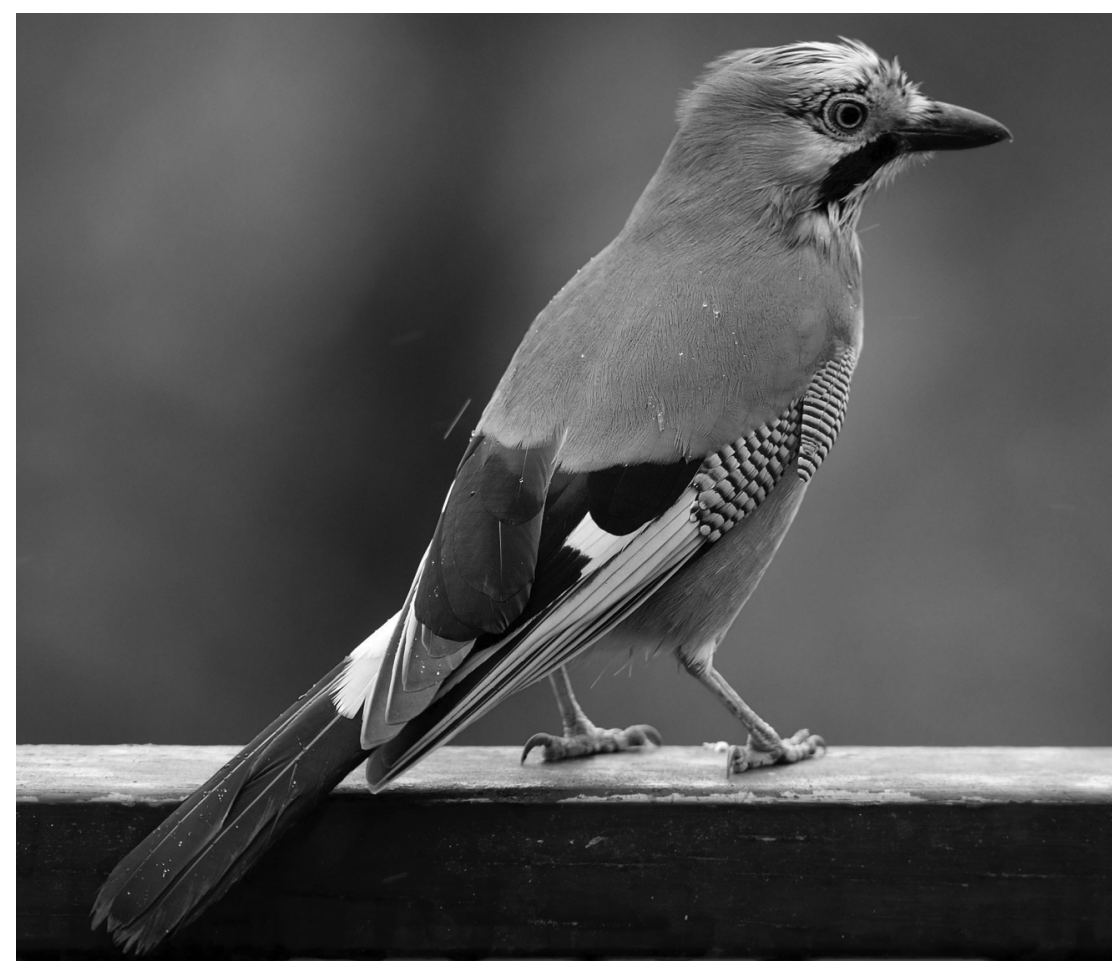

FIG. 6. - The Eurasian jay (Garrulus glandarius). Photo B. Luc Viatour/ Wikimedia Commons.

hide. It may have had sleeves since some of the wing bones and tooth pendants occurred beside the right elbow. The location of the animal tooth pendants suggests a costume extending from the shoulders to the knees.

Interestingly enough, three jay carpometacarpal bones were also found in another Middle Neolithic burial of an adult male in grave number 165 (Fig. 5) (Mannermaa 2008a). The buried person in this grave also wore animal tooth decorations. The species used were red deer, dog, European elk, the pine marten (Martes martes) and an unspecified seal (Phocidae) (Lóugas 2006: 84). The radiocarbon date for one of the jay specimens in grave 165 falls into the same time range as the human remains (Mannermaa et al. 2007), indicating that they are of the same age, and that the jay bones most probably belong to the burial. Furthermore, two jay carpometacarpal bones were found in the badly disturbed Zvejnieki grave 167. Unfortunately, due to damage, this burial could not be accurately reconstructed. Carpometacarpal bones and 28 tooth pendants were found at the base of the grave pit, which held the remains of two people, a male and a female. All the graves with jay bones are located near each other. I assume that the jay bones in all these graves derive from the blue wings that were attached to the costume (Fig. 6).

\section{Blue COLOUR SYMBOLISM?}

Jay wings appear to have been used in the decoration of burial garments or wrappings, but they also had several other more fundamental meanings, probably connected to the symbolic world and its ideology. The jay may have been an important animal for the whole community, but it is also possible that the blue colour of the feathers may have been the reason for using jay wings. Preference for certain colours has been documented in prehistoric and ethnographic research (e.g., Jones \& Bradley 1999; 
Jones \& McGregor 2008). A particular significance of the colour red is indicated in use of red ochre in prehistoric burials and rock art, and in ethnographic descriptions (e.g., Okladnikov 1950; Karsten 1955: 119, Nuñez 1986: 25; Stjernquist 1998: 273).

\section{THE JAY AS A TOTEM ANIMAL}

The jay may well have been a totem animal for the Middle Neolithic group at Zvejnieki. The people buried in graves 164, 165 and 167 may have been important members of the group (leaders or shamans?), and parts of wings, perhaps representing the flying ability of the totem bird, decorated their burial dresses. The same garments were probably used in rituals when these people were alive. Indications of animal totemism (the brown bear Ursus arctos, the Eurasian elk, the Eurasian beaver, the whooper swan, the grass snake Natrix natrix etc.) are known from a number of prehistoric and historic sites in northern Europe (e.g., Tilley 1991; Ernits 1992: 116; Zvelebil 1997: 45; Loze 2003). The jay, like other species in the Corvidae family, is a social and very visible bird. It lives in forested areas, but is not afraid of settlement areas and people. It is omnivorous and has the habit of burying food for winter in the autumn. Jays are drawn to carrion and refuse heaps. Jays imitate the calls of other birds and may live to a very old age for a bird. They are local birds, but known for their irruptive migrations (Haartman et al. 1963-1972: 703-708). In other words, there are obvious similarities in the social and migratory behavior of jays and people; both are sedentary but wander in certain circumstances or seasons. Considering these qualities, it would not be surprising if these people living at Zvejnieki really felt a certain kinship with them.

\section{THE OSPREY AT YUZHNIY OLENIY OSTROV}

\section{THE SITE}

The cemetery island of Yuzhniy Oleniy Ostrov, the largest known Mesolithic cemetery in northern Europe, is located on Lake Onega, Karelia in western Russia (Fig. 1). At least 170 burials were identified during archaeological excavations in 1936-1938, led by the Russian archaeologist V.I. Ravdonikas (Ravdonikas 1956; Gurina 1956). Unfortunately the site was already partly disturbed when the first excavation took place. The original number of burials may have exceeded 400-500 (Gurina 1956; Jacobs 1995). During the three field seasons, an area of $2700 \mathrm{~m}^{2}$ was excavated (Jacobs 1995: 365). The whole burial area is marked by relatively similar burial practices. The orientation of the long axis in all determinable burial pits was roughly from east to west and red ochre surrounded almost all the skeletons (Gurina 1956). The selection of grave goods varied between the graves, but animal tooth pendants were found in most of the graves. Other grave goods include, for example, bone, stone and antler utensils (such as arrowheads, spearheads, knives and scrapers), zoomorphic (mainly brown bear, European elk, and snakes), and anthropomorphic figurines, and unmodified animal bones (Gurina 1956; O’Shea \& Zvelebil 1984). Radiocarbon dates on human skeletal samples from five burials date the cemetery to approximately 7700-7300 BP (c. 7000-6200 cal BC) (Price \& Jacobs 1990).

The human and other mammal remains were analysed soon after the excavations and published in Gurina's volume (1956). Anatomical and taxonomic identification of the bird bones from Yuzhniy Oleniy Ostrov burials was conducted in 2006 (Mannermaa et al. 2008). Bird bones from the graves derive from various species, the most common being the osprey (Pandion haliaetus) with 72 identified specimens. Other identified species are the great-crested grebe (Podiceps cristatus), the white-tailed eagle (Haliaeetus albicilla), the blackthroated diver (Gavia arctica), the great grey owl (Strix nebulosa), the mallard (Anas platyrhynchos), the long-tailed duck (Clangula hyemalis), the garganey (Anas querquedula), the western capercaillie (Tetrao urogallus) and the herring gull (Larus argentatus).

Unmodified bird bones in Yuzhniy Oleniy Ostrov graves were stored in a small box at the Zoological Institute of Saint Petersburg, separately from unmodified mammal bones and artefacts. Unfortunately, most specimens (113 of 132) have lost their precise archaeological contexts as the grave number attached to the bones has disappeared (Mannermaa et al. 2008). Only 21 bird bones can be connected to a 


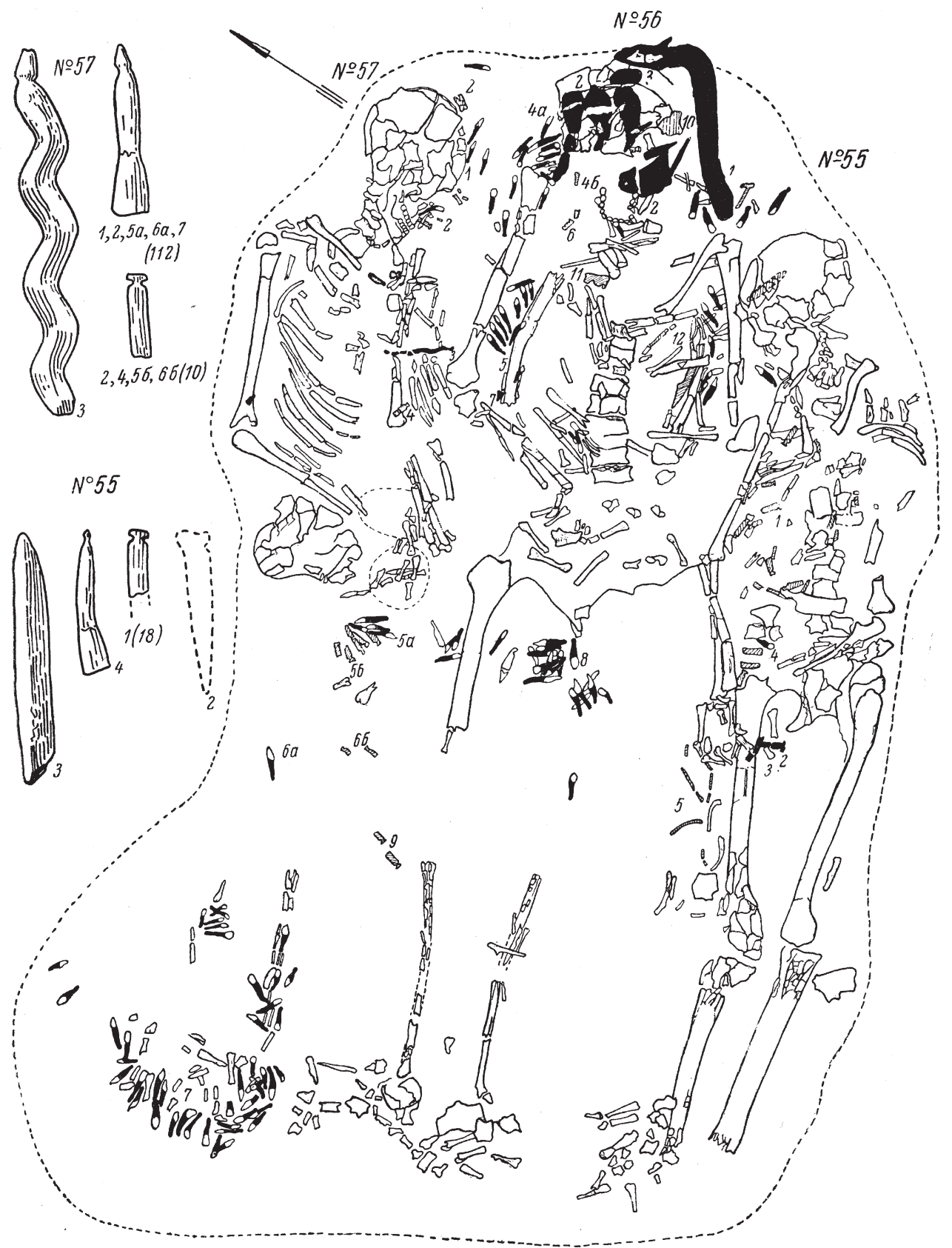

FIG. 7. - The Late Mesolithic collective grave 55-57 of two females and a male at Yuzhniy Oleniy Ostrov, northwestern Russia. Five fragments of leg bones (left fibula, right femur, two right one one left tibiotarsi) from the osprey (Pandion haliaetus) and a wing bone (carpometacarpus) of the great gray owl (Strix nebulosa) were found in the thoractic and vertebral region of adult male in burial 56 (find no 12). Adopted from Gurina 1956. 


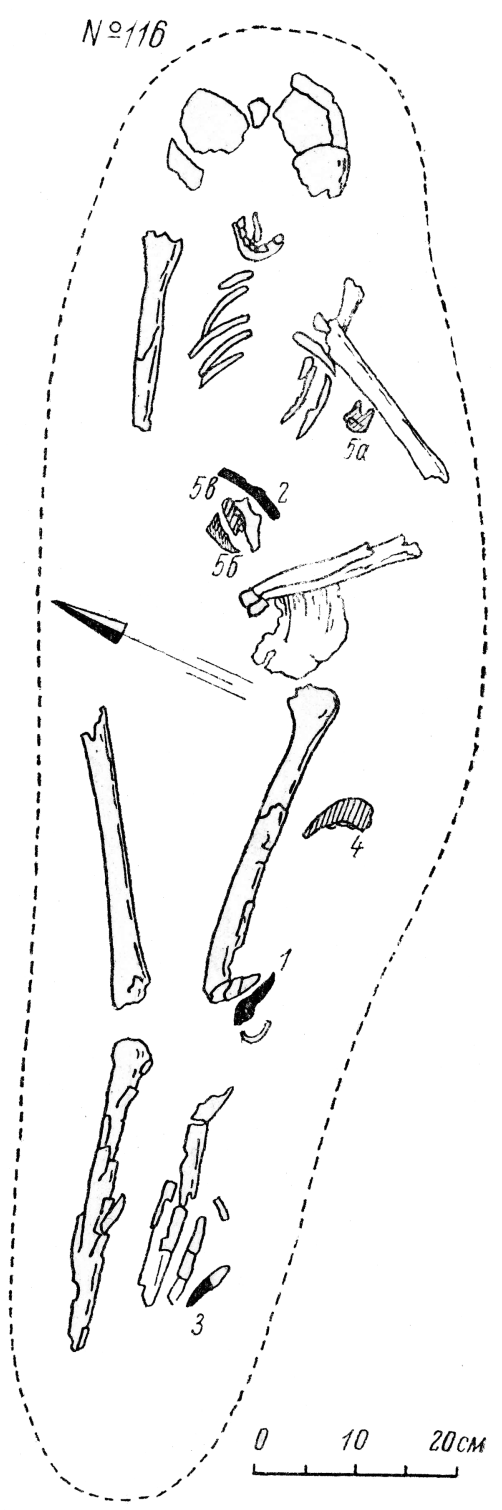

FIG. 8. - The Late Mesolithic grave 116 of a juvenile at Yuzhniy Oleniy Ostrov, northwestern Russia. Two fragments, one from the scapula and the other from the coracoid of an osprey (Pandion haliaetus) were found at the waist or the abdominal area of the deceased (number 5b) Adapted from Gurina 1956.

particular grave, but lack the precise burial context. Gurina (1956) mentions bird bones in 22 graves, and she also shows the precise location of each bird bone, as well as other animal bones, in illustrations.
This information was used only for the specimens with a grave number still attached to them, but in most cases it is not possible to associate the species with a precise burial context.

One osprey bone in grave 56 was radiocarbon dated with AMS, and gave the radiocarbon age of 7570 \pm 60 BP (Hela-1374) (c. 6570-6256 cal BC) (Mannermaa et al. 2008). Two dates taken from the human skeleton in burial 57 have yielded dates of $7280 \pm 80$ BP (Oxa-1665) (c. 6357-6004 cal BC)

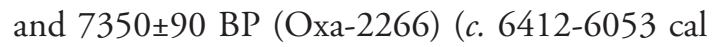
BC) (Price \& Jacobs 1990: 851) (calibrations were performed using the program $\mathrm{OxCal}$ 4.0). The calibrated age of the osprey in burial 56 and the human in burial 57 overlap, which implies that all humans in grave 55-57 were buried at the same time.

\section{OSPREYS IN GRAVES 55-57 AND 116 AT YUZHNIY OleniY OSTROV}

Out of the 72 identified osprey specimens at Yuzhniy Oleniy Ostrov, only seven could be connected to a specific grave, five to a multiple grave 55-57 and two come from grave 116. All other bones have lost their context. The anatomical parts deriving from ospreys in the whole cemetery are shoulders, wings and legs, although the clear dominance of tibiotarsus, a leg bone, is apparent (almost half of all osprey bones) (Mannermaa et al. 2008). The minimum number of osprey individuals in the cemetery is fourteen. Cutmarks are present on fourteen osprey specimens: thirteen distal parts of tibiotarsi (leg bones) and one proximal part of a scapula (shoulder blade).

Five of the osprey bones were found in the collective grave 55-57, which contained three adult burials. An elderly man was placed at the centre on his back (number 56), and burials of two adult women (numbers 55 and 57) were placed on both sides (Gurina 1956; Grünberg 2000) (Fig. 7). No bird bones were reported in burial 57 . Thirteen bird bones were reported at the right hand of the female in burial 55 (Gurina 1956: 302). However, only one bird bone in our material, a diaphysis of an unspecified bird, bore this burial number. The other grave goods in grave 55 are two bone artefacts, a bone point and a tooth pendant made of an elk incisor beside the right femur, and beaver incisor tooth pendants at the thorax area (Grünberg 2000). 


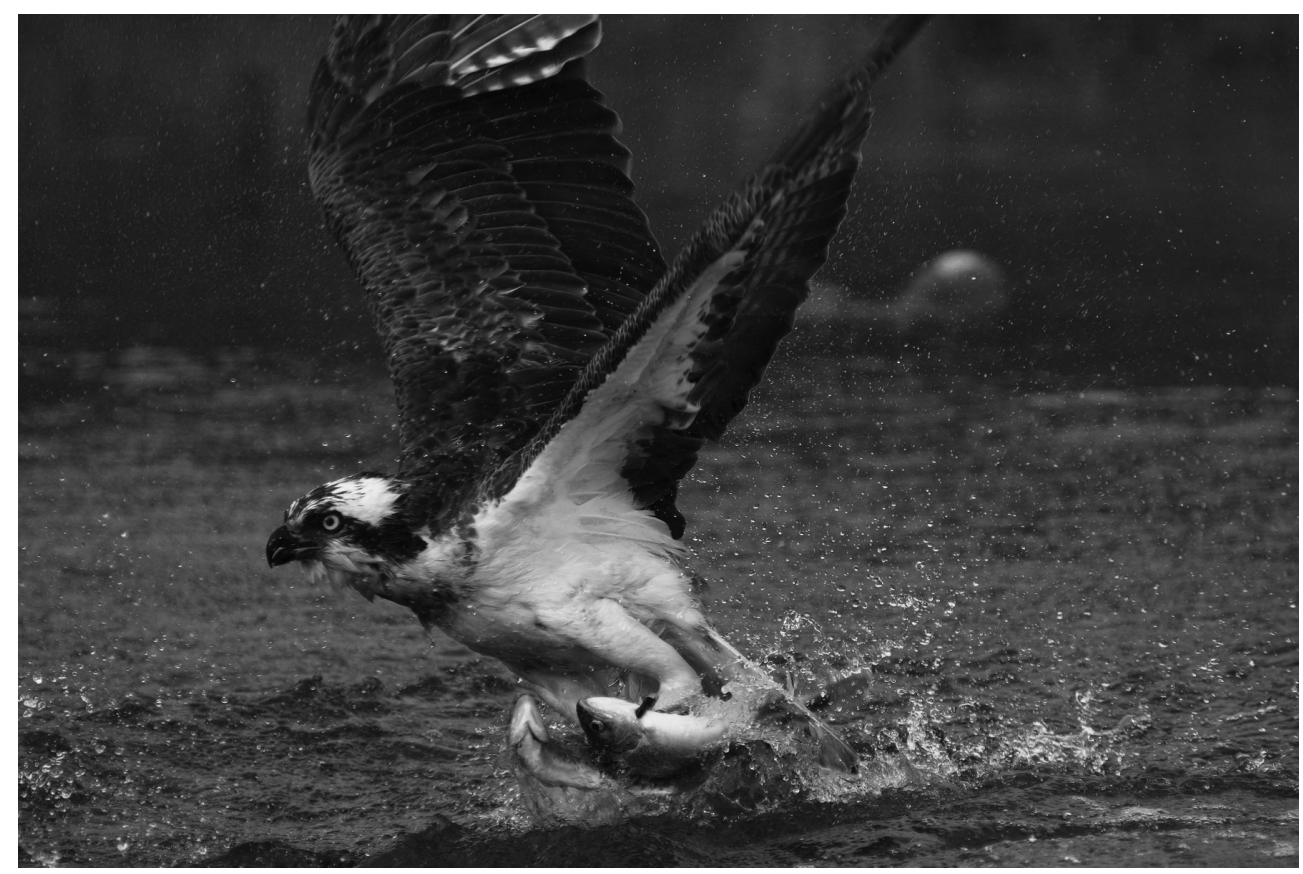

FIG. 9. - The osprey (Pandion haliaetus) fishing. Photo Janne Kortesaari / Vastavalo.fi.

Burial 56 was richly adorned. Gurina (1956: 302) mentions that bird bones were found in the thoracic and vertebral regions, together with tooth pendants made of wild reindeer. Six bird bones belonging to grave 56 can be identified, five of which are from the osprey (a left fibula, a right femur, two right and one left tibiotarsi, from the leg) and one from the great grey owl (Strix nebulosa) (carpometacarpus, from the distal wing). Four of the osprey bones are thickly covered with red ochre, and the owl bone is both covered and filled with it. A wolf bone (Canis lupus) was found at the right clavicle. Tooth pendants made of wild reindeer, elk and beaver incisors were found at the skull and shoulders, and on the upper arms and upper legs. A large mace made of reindeer antler depicting an elk head was found on the left side of the skull. A fragmentary slate knife, a flint artefact, and a fragment of a stone knife were found in the region of the head, and a bone artefact was found at the left elbow $(\mathrm{Gu}-$ rina 1956: 302).
Fragments of bird bones were found in the waist or stomach area of the deceased in grave 116 (Gurina 1956: 352). The skeleton of this juvenile person was poorly preserved. A beaver mandible, fragmentary beaver bones and a wolf tooth were found in the same area with bird bones (Fig. 8). Two bird bones from grave 116 were found and identified as a scapula and coracoid (both from the shoulder) of osprey (Mannermaa et al. 2008). The coracoid is covered with red ochre and there are cutmarks on the scapula. Other grave goods are scarce: a fragment of a bone pendant and a bone brooch were found near the beaver mandible and bird bones, a bear canine at the right knee and an elk incisor at the right foot. Red ochre covered the whole grave.

\section{THE POWER OF THE OSPREY}

It is evident that the osprey plays a special role in the ideology of the people who used the cemetery. In burial 56 one, probably two legs, the right and left, were deposited at the thorax region of the deceased. In burial 116, parts of a wing were deposited at the waist or stomach area of a child. Even though we 
don't know which graves contained osprey bones, the minimum number of bird individuals in the whole cemetery, 14 , is impressive. Shoulder bones, humeri and femora could be remains of food offerings (meat from the breast and the leg). A relatively large number of humeri might also indicate that wings, probably with feathers still attached, could have been deposited in graves. However, this does not seem likely as other wing bones (radii and ulnae) are totally lacking. The deposition of foot elements and especially the high number of tibiotarsi at the cemetery is striking. No taphonomical reasons can explain the abundance of tibiotarsi, as this bone is not generally among the well-preserved bird bones (e.g., Higgins 1999). It is possible that the osprey legs were deemed to be particularly important as they play an important role in fishing: ospreys take fish with their feet from shallow water and carry them in their talons to the nest for dismemberment and consumption (Fig. 9).

A preliminary study revealed that many of the osprey tibiotarsi from the whole cemetery show cutmarks on their distal part (Mannermaa et al. 2008). This may indicate that the meat from legs was consumed. As no talons were found in graves, they must have been deposited at some other place. For some reason, people wanted to separate these two parts, the leg and the ankle/talon of the osprey. In order to learn more about what kind of activity has caused the cutmarks on tibiotarsi, a systematical investigation is required.

\section{DISCUSSION}

\section{The Jay And PeOple at Middle NeOlithic ZVEJNIEKI}

Three individuals, probably all males, have jay wings (or wing bones) in their graves, which makes these graves special in Zvejnieki. It is likely that wings were attached to a dress of the dead and must have been an important part of the grave decoration and appearance. The blue colour of jay wings was probably an important reason for using these particular parts. The use of wing parts may also have symbolic significance, for example, connected with altering states of consciousness.
In addition to jay bones, there are also other special features in burials 164 and 165 that support the idea that the people buried in these graves were not, so called ordinary people. The sixteen bone spearheads between the legs of the deceased in grave 164 are unique at Zvejnieki. The nutritional history of the man in grave 165 is interesting as stable isotope analysis indicates a mixed marine and freshwater protein intake in his diet (Eriksson 2006: 192, 2007). This contrasts with the isotope values of human bones from all the other burials at Zvejnieki (a total of forty human samples have been measured), which indicate dependence on freshwater fish (Eriksson et al. 2003; Eriksson 2006). The man in grave 165 probably grew up in Zvejnieki, then presumably lived near the Baltic Sea for several years, and returned to Zvejnieki as an adult (Eriksson 2007). Furthermore, stable isotopes reveal that his dog also spent some time on the coast, and is the only case of this among the dogs buried at Zvejnieki (Eriksson and Zagorska 2003). The man and his dog in grave 165 clearly have a different history from other people and dogs buried in Zvejnieki.

\section{OSPREYS AND OTHER BIRDS OF PREY AT LATE Mesolithic YuZHNiY Oleniy OSTROV}

In addition to the ospreys and the great grey owl, several white-tailed eagle bones were found in burials at Yuzhniy Oleniy Ostrov (Mannermaa et al. 2008). The white-tailed eagle has a different elemental distribution from that of the osprey in that only bones from the shoulders (the coracoid and scapula) were identified. This is in contradiction with data from many other archaeological sites, where bird of prey leg and foot (phalanges) bones are most common (Mannermaa 2003; Guminski 2005). The coracoidii and scapulae can be hard to remove when a bird is filleted and the breast muscles are taken off. The deposition of the scapulae and coracoidii may indicate that breast muscles of white-tailed eagles were deposited in graves as food offerings. It is also possible that the meat was consumed during the funeral. None of the whitetailed eagle bones could be related to a particular grave, and we do not know for sure whether both scapulae and coracoidii are found in the same burials. 
TABLE 1. - The taxonomic distribution of animal bones at the Late Mesolithic settlement 1 in Yuzhniy Oleniy ostrov, western Russia. The site was excavated by A. Murashkin in 2007, osteological analysis was made by Kristiina Mannermaa (2008b).

\begin{tabular}{|c|c|c|}
\hline & NISP & MNI \\
\hline $\begin{array}{l}\text { Rangifer tarandus (wild reindeer) } \\
\text { Rangifer tarandus/Alces alces (wild reindeer/European elk) } \\
\text { Canis familiaris (dog) } \\
\text { Canis familiaris/Canis lupus (dog/wolf) } \\
\text { Castor fiber (European beaver) } \\
\text { Lepus timidus (mountain hare) } \\
\text { Mammalia (indet. mammal) } \\
\text { Anatidae (indet. duck) } \\
\text { Coregonus lavaretus (whitefish) } \\
\text { Salmo salar/Salmo trutta (salmon or brown trout) } \\
\text { Salmonidae (salmonid fish) } \\
\text { Esox lucius (European pike) }\end{array}$ & $\begin{array}{c}3 \\
1 \\
13 \\
5 \\
1 \\
6 \\
1145 \\
2 \\
618 \\
6 \\
61 \\
29\end{array}$ & $\begin{array}{c}10 \\
1\end{array}$ \\
\hline
\end{tabular}

However, this appears to be likely. Considering the anatomical distribution of bones from the osprey and the white-tailed eagle at Yuzhniy Oleniy Ostrov, I would suggest that these two birds had different ideological significance in the burial practices of the people who used the cemetery.

Why were osprey and other birds of prey particularly significant for the Late Mesolithic people? The osprey, the white-tailed eagle and the great grey owl are characterized by a large size, majestic appearance, and excellent and specified hunting skills. The characteristics of these birds, such as visual acuity, force and sheer power, must have been valued by humans.

In 2006 and 2007, a group of Russian archaeologists excavated two areas with occupation traces on the island of Oleniy Ostrov (Murashkin et al. 2008). One of these dates to the Middle Mesolithic and yielded only a few bones. The other has been dated to the Late Mesolithic and yielded a large quantity of bone material. At both areas only burnt bones were preserved. The results of the osteological analysis from the Late Mesolithic settlement indicate that the whitefish (Coregonus lavaretus) was important in the food economy (Mannermaa 2008b) (Table 1). If we consider that the same people who left the occupation traces were those who used the cemetery (at least partly), we can say that people shared the same food resources with ospreys and white-tailed eagles.

The ospreys and the white-tailed eagles were probably hunted in the vicinity of the island. The easiest way to catch these species, and birds of prey in general, would be to climb up to the nest and capture the chicks. Adult ospreys, owls and eagles could have been captured with traps or shot with arrows. The archaeological material indicates that white-tailed eagles were kept in captivity in the Early Iron Age site in northwestern Siberia (Potapova \& Panteleyev 1999). This ritual site complex bears the earliest evidence of eagle worship in northern Europe. However, the bone specimens of the great grey owl, the osprey and the white-tailed eagle found in the cemetery belong to fully-grown animals. None of the bones derive from young individuals, and no clear marks, scars, healed fractures etc., indicate that these birds were kept in captivity. At this stage of research, the lack of definite traces does not exclude the possibility that birds of prey were raised for offering and other purposes.

Today, ospreys are relatively common in the southeastern area around Lake Onega (Zachos \& Schmölcke 2006). The nests are mostly concentrated on the shores of small lakes around the southwestern area of Lake Onega (Kuznetsov \& Babushkin 2005). The number of breeding pairs is about 150-180, while the population of the white-tailed eagle is approximately 100 (Kuznetsov \& Babushkin 2005). These species were also common and represented the typical fauna of the Onega area in prehistoric times. The osprey and the white-tailed eagle are good representatives of this environment and landscape and this may have been the reason for placing these species in the graves. 
SPIRIT HELPERS AND WINGS

In this article, I have shown that several lines of interpretation exist concerning the roles of jays and ospreys in burial practices. Both species could well represent shaman helper spirits. The jay burials in Zvejnieki may be interpreted as a potential indication of totemism, and they also indicate some kind of high-class status of the dead, perhaps that of a group leader or a shaman. Perhaps the people with high status had the finest costumes in prehistory, but it is also likely that individuals with higsh status received a ceremonial burial and a richly-adorned grave. Bird parts could even be seen as representing a shamanic metamorphosis - with the help of a supernatural bird, a shaman could attain another state of being in life and death.

According to Gurina (1956), all bird bones in burial 56 at Yuzhniy Oleniy Ostrov were found near the thorax or vertebral region, which means that they were probably attached to a dress or hanging from a string together with other artefacts (wild reindeer tooth pendants). These may have been magical objects or symbols of powerful animals. Two osprey wing bones (probably representing a complete wing) were placed at the waist or stomach area of a child in burial 116. Some burial finds of birds at other northern European archaeological sites confirm the importance of wings. The symbolic significance of a swan wing in a child burial is evidenced in a Late Mesolithic double grave at Vedbæk Bøgebakken (Albrethsen \& Brinch Petersen 1976). Burial VII at Tamula contained a child buried on his/her back, with unmodified crane ulnae near the hands (Jaanits 1954). Furthermore, at Neolithic Tamula, an adult male had a golden eagle radius in a cluster of finds between his vertebrae and left hand, and another adult, probably a female, had a capercaillie radius near the head (Jaanits 1957: 81, 86). Such graves with bird wings or parts of wings deposited near the hands give the impression that these birds may have had a carrier role between different places or states of being. Bird wings or their parts transported the soul to the afterlife. Bird wings could also have a protective function, perhaps especially in the graves of children.

It is known from ethnographic sources that water birds (for example, whooper swans, ducks and di- vers) were central components in the belief systems and world conception of circumboreal and Uralic communities (Ingold 1986; Napolskikh 1992). A widely distributed part of these mythologies is the perception of birds as carriers or messengers between the people on earth and the gods or spirits (Napolskikh 1992:11-12; Zvelebil \& Jordan 1999:109). The symbolic representation of birds as transporters between the human and the spiritual world has been emphasized in interpretations of prehistoric Stone Age rock art (Ernits 1992; Stolyar 2000; Lahelma 2008).

\section{CONCLUSIONS}

In this article I underline the fact that bird bones from funerary contexts yield interesting information about prehistoric ideologies and burial practices. Here I give two examples of birds, the Eurasian jay and the osprey, of special local significance for groups of prehistoric hunter-gatherers. In sum, the jay and osprey remains indicate prehistoric ideology that can be interpreted as representing totemism and shamanism. Deposition of wings or parts of wings might indicate the role of the bird as a carrier or transporter (of the soul to the afterlife). Wing bones in child burials may have a specific function and meaning, probably connected to protection and/or transformation or transport. The deposition of osprey legs may indicate that the power of this bird was particularly appreciated and re-mobilized in burials.

\section{REFERENCES}

Albrethsen S. E. \& Brinch Petersen E. 1976. Excavation of a Mesolithic cemetery at Vedbæk, Denmark. Acta archaeologica 47: 1-28.

BuRENHUlT G. 1997. - Gravarnas vittnesbörd, in BURENHULT G. (ed), Ajvide och den moderna arkeologin: 52-70. Natur och kultur, Falköping.

CARPELAN C. 1975. — Älg- och björnhuvudföremål från Europas nordliga delar. Finskt Museum 1974: 5-67.

EBERHARDS G. 2006 . - Geology and development of the paleolake Burtnieks during the Late Glacial and Holocene in LARSSON L. \& ZAGORSKA I. (eds), Back to the Origin. New Research in the Mesolithic-Neo- 
lithic Zvejnieki Cemetery and Environment, Northern Latvia. Acta Arheologica Lundensia Series 8, 52: 25-51.

Eliade M. 1964. - Shamanism: Archaic Techniques of Ecstasy. Princeton, Princeton University Press.

ERIKSSON G. 2006. - Stable isotope analysis of human and faunal remains from Zvejnieki, $i$ N LARSSON L. \& ZAGORSKA I. (eds), Back to the Origin. New Research in the Mesolithic-Neolithic Zvejnieki Cemetery and Environment, northern Latvia. Acta Archaeologica Lundensia Series in 8, no 52. Almqvist \& Wiksell, Stockholm: 183-216.

ERIKSSON G. 2007. — Immigrant, returnee or commuter?, in HÅrdh B., JenNBERT K. \& OlausSON D. (eds), On the road. Studies in honour of Lars Larsson. Almqvist \& Wiksell International, Stockholm: 188-192.

ERIKSSON G. \& ZAGORSKA I. 2003. - Do dogs eat like humans? Marine stable isotope signals from dog teeth from inland Zvejnieki, in LARSSON L., KINDGREN K, KnutTSON K, LOefFler D \& ÅKerLund A. (eds), Mesolithic on the Move. Papers presented at the Sixth International conference on the Mesolithic in Europe, Stockholm 2000. Oxbow books, Oxford : 160-168.

ERIKSSON G., LÕUGAS L., ZAGORSKA I. 2003. — Stone Age hunter-fisher-gatherers at Zvejnieki, northern Latvia: stable isotope and archaeozoological data. Before Farming 1:1-25.

ERNITS E. 1992. - The purpose and content of the petroglyfs in the Onega region, in Hoppal M. \& PeNTIKÄINEN J. (eds), Northern religions and Shamanism. Akadémiai kiadó, Budapest: 115-124.

FAHLANDER F. 2004. - Archaeology and Anthropology - brothers in arms. on analogies in $21^{\text {st }}$-century archaeology in FAHLANDER F. \& OESTIGAARD T. (eds) Material Culture and Other Things. Post-disciplinary Studies in the 21 $1^{\text {st }}$ Century. GotArc Series c, vol. 61. University of Gothenburg, Gothenburg: 185-212.

GuRINA N. 1956. — Oleneostrovskij mogilnik. Materialy $i$ issledovanija po archeologiji SSSR 47. MoskvaLeningrad.

GÜNTHER H. 2009. — Problem med schamanistiska tolkningar av de nordfennoskandiska hällbilderna. Fornvännen 104: 17-33.

GRÜNBERG J. M. 2000. — Mesolithische Bestattungen in Europa. Ein Beitrag zur vergleichenden Gräberkunde. Teil. 1-2 . Internationale Archäeologie Band 40. Verlag Marie Leidorf GmbH, Raahden/Westf.

GuMINSKI W. 2005. — Bird for dinner: Stone Age hunters of Dudka and Szczepanki, Masurian Lakeland, NE-Poland. Acta Archaeologica 76: 111-147.

HaArtman L. Von, Hilden O., Linkola P., SuOmalaiNen P., Tenovuo R. 1963-1972. - Pohjolan linnut värikuvin. Otava.

Harvey G. 2005. - Animism. Respecting the Living World. Hurst \& Company. London.

Higgins J. 1999. — Tunel: A Case Study of Avian Zoo- archaeology and Taphonomy. Journal of Archaeological Science 26: 1446-457.

HULTKRANTZ A. 1987. - On beliefs in non-shamanic guardian spirits among the Saami in AHLBÄCK T. (ed.), Saami religion. Scripti Institituti Donneriani Aboenses XII: 110-123. Almqvist \& Wiksell International, Stockholm.

INGOLD T. 1986. - Appropriation of Nature. Essays on Human Ecology and Social Relations. Manchester University Press. Manchester.

IngOLd T. 2000. - The Perception of the Environment. Essays on livelihood, dwelling and skill. Routledge, London

JAANITS L. 1954. - Novye dannye po neolitu Pribaltiki. Sovetskaya Arkheologiya 19: 159-204.

JAANITS L. 1957. — Neue Gräberfunde auf dem spätneolithischen Wohnplats Tamula in Estland. Suomen muinaismuistoyhdistyksen aikakauskirja 58: 80-100.

JAANITS L. 1961. - Jooni kiviaja uskumusest. Religiooni ja ateismi ajaloost Eestis. Artikliste koguunik II. Tallinn: 5-70.

JACOBS K. 1995. - Returning to Oleni' ostrov: Social, Economic, and Skeletal Dimensions of a Boreal Forest Mesolithic Cemetery. Journal of Anthropological Archaeology 14:359-403.

JANZON G.O. 1974. - Gotlands mellanneolitiska gravar. Studies in North-European Archaeology 6. Stockholm.

JONES A. 1998. - Where eagles dare. Landscape, animals and the Neolithic of Orkney. Journal of Material Culture 3: 301-324.

JONES A. 1998. - Where eagles dare. Landscape, animals and the Neolithic of Orkney. Journal of Material Culture 3: 301-324.

JONES A. \& BRADLEY R. 1999. - The significance of colour in European archaeology. Cambridge Archaeological Journal 9 (1): 112-114.

Jones A. \& MCGregor G. (eds) 2008. - Colouring the Past: the Significance of Colour in Archaeological Research. Oxford.

Jones O'Day, S., VAn NEer W. \& ERWynck A. 2004.INTRODUCTION IN JONES O'DAY, JONES O'DÁY S., VAN NEER W. \& ERWYNCK A. (eds), Behaviour Behind Bones. The Zooarchaeology of Ritual, Religion, Status and Identity: xi-xv. Proceedings of the 9th Conference of the International Council of Archaeozoology, Durham, August 2002. Oxbow Books, Oxford.

JONSSON L. 1986. - Fish bones in late Mesolithic human graves at Skateholm, Scania, South Sweden in BrinkHuizen D. C. \& Clason A. T. (eds.), Fish and Archaeology. Studies in Osteometry, Taphonomy, Seasonality and Fishing Methods. BAR International Series S294: 62-79.

JORDAN P. 2004. - Examining the role of agency in hunter-gathere cultural transmission in GARDNER A. (ed.), Agency Uncovered. Archaeological Perspectives on Social Agency, Power and being Human: 107-134. 
UCL Press, London.

Karsten R. 1955. - The Religion of the Samek. Ancient Beliefs and Cults of the Scandinavian and Finnish Lapps. E.J. Brill, Leiden.

Kuznetsov A.V. \& Babushrin M.V. 2005. - The white-tailed sea eagle Haliaeetus albicilla and the osprey Pandion haliaetus in the Vologda Lake District and Southeastern Onego Area. Status of raptor popolations in Eastern Fennoscandia. Proceedings of the Workshop, Kostamuksha, Karelia, Russia. November 8-10. 2005

LaHelma A. 2005. - Between the worlds. Rock Art, Landscape and Shamanism in Subneolithic Finland. Norwegian Archaeological review 38 (1): 29-47.

LAHELMA A. 2008. - A touch of red. Archaeological and Ethnographic Approaches to Interpreting Finnisk Rock Paintings. ISKOS 15.

Lahelma, A, 2012. - Strange Swans and Odd Ducks: Interpreting the Ambiguous Waterfowl Imagery of Lake Onega. In Visualising the Neolithic: abstraction, figuration, performance, representation. A. Cochrane \& A. Jones, eds. Oxbow Books, Oxford: 15-33.

LARSSON L. 1989. - Big dog and poor man. Mortuary practices in Mesolithic Societies in Southern Sweden, in LARSSON T.B. \& LuNDMARK H. (eds), Approaches to Swedish Prehistory. A spectrum of problems and perspectives in contemporary research: BAR International Series 500: 211-223. Archaeopress, Oxford.

LARSSON L. 1990. - Dogs in fraction - symbols in action, in Vermeerch P.M. \& Van Peer P. (eds), Contribution to Mesolithic in Europe. Papers presented at the Fourth International Symposium "The Mesolithic in Europe", Leuven 1990. Studia Praehistorica Belgica 5: 153-160.

LARSSON L. 2006. - Tooth for a tooth for a grave. Tooth ornaments from the graves at the cemetery of Zvejnieki, in LARSSON L. \& ZAGORSKA I. (eds.) Back to the Origin. New Research in the Mesolithic-neolithic Zvejnieki Cemetery and Environment, northern Latvia. Acta Archaeologica Lundensia Series 8, 52: 153-288.

LARSSON L. 2010. - A double grave with amber and bone adornments at Zvejnieki in Northern Latvia. Archaeologica baltica 13: 80-89.

LEWIS-WILLIAMS J.D. 2003. — Putting the record straight: Rock art and shamanism. Antiquity Vol. 77 No. 295: 165-169.

Losey R.J., Bazaliskit V.I., GarVIE-LOK S., GermonprÉ M., Leonard J.A., Allen A.L., Katzenberg M.A. \& Sablin M. 2011. - Canids as persons: Early Neolithic dog and wolf burials, Cis-Baikal, Siberia. Journal of Anthropological Archaeology 30:174-189.

LOZE I. 1993. - The theme of the grass snake in Neolithic material from Latvia. Humanities and Social Sciences, Latvia 2: 48-59.

LŌUGAS L. 2006. - Animals as subsistence and bones as raw material for settlers of prehistoric Zvejnieki, in LARSSON L. \& ZAGORSKA I. (eds), Back to the
Origin. New Research in the Mesolithic-Neolithic Zvejnieki Cemetery and Evironment, northern Latvia. Acta Archaeologica Lundensia Series 8, 52: 75-90.

LÖNNQVIST B. 1986. - Schamandräkter i Sibirien. Former och funktioner, alder och ursprung. Finskt Museum 1985: 81-94.

Mannermaa K. 2003. - Birds in Finnish prehistory. Fennoscandia archaeologica xx: 3-39.

MANNERMAa K. 2006. - Bird remains in the human burials at Zvejnieki, Latvia. Introduction to bird finds and a proposal for interpretation, in LARSSON L. \& ZAGORSKA I. (eds.) Back to the Origin. New Research in the Mesolithic-Neolithic Zvejnieki Cemetery and Environment, northern Latvia. Acta Archaeologica Lundensia Series 8, 52: 289-30.

MannermaA K. 2008A. - Birds and burials at Ajvide (Gotland, Sweden) and Zvejnieki (Latvia) about 8000-3900 BP. Journal of Anthropological Archaeology 27: 201-225.

ManNeRMaA K. 2008B. - Yuzhniy Oleniy Ostrov $1 /$ Anton Murashkin 2007. Unpublished osteological report at the Department of Philosophy, History, Culture and Art Studies, Archaeology, University of Helsinki.

MANNERMAa K., ZAGORSKA I., JUNGNER H. \& ZARINA G. 2007. - New radiocarbon dates of human and bird bones from Zvejnieki Stone Age burial ground in northern Latvia. Before Farming 1/2007.

Mannermaa K., Panteleyev A. \& Sablin M. 2008. — Birds in Late Mesolithic burials at Yuzhniy Oleniy ostrov (Lake Onega, western Russia) - What do they tell about humans and environment? Fennoscandia archaeologica XXV: 3-25.

Murashinin A.I., Tarasov A.Ju., German, K.È. \& MANNERMAA, K. 2008. - Kompleks mezolitičeskih pamjatnikov na Južnom Olen'em ostrove Onežskogo ozera: problemy planigrafii i hronologii. Oral presentation at the IVth Tver Archaeological Conference and the 12th Meeting of Scientific and Methodic Seminar "Tver Land and Neighbouring Territories in Ancient Times", 25-29.3.2008.

NAPOLSKIKH V. 1992. - Proto-Uralic world picture: a reconstruction, in HOPPAL M. \& PENTIKÄINEN J. (eds.) Northern Religions and Shamanism: 3-20, Akadémiai kiadó, Budapest.

NiLSSON STUTZ L. 2009. — Coping with cadavers: ritual practices in Mesolithic cemeteries, in MCCARTAN S., SChUlting R., Warren, C. \& WoOdman P (EDS) Mesolithic Horizons. Papers presented at the sevent International conference of the Mesolithic in Europe, Belfast 2005, Vol II. Oxbow books, Oxforsd and xx: 657-663.

NiLSSON STUTZ L., LARSSON L. \& ZaGORSKA I. 2008. More burials at Zvejnieki. Preliminary results from the 2007 excavations. Mesolithic Miscellany 19 (1): 12-16.

NuÑEZ M. 1986. — Clay figurines from Åland Islands and Mainland Finland. Fennoscandia archaeologica III: $17-34$. 
OKLADNIKOV A.P. 1950. — Kult medvedya u neolitischeskik plemen ostochnoi Sibiri. Soryetskaya Arkheologiya 14: 7-19.

OsHibKINA S.V. 1982. — Mezoliticheskiy mogil'nik Popovo na ryeke Kineme. Soryetskaya Arkheologiya 3: 122-138.

Potapova O. R. \& Panteleyev A. V. 1999. — Birds in the economy and culture of Iron Age inhabitants of Ust' Poluisk, lower Ob' River, North Western Siberia, in Olson S. T. (ed), Avian Paleontology at the Close of the 20th Century: Preoceedings of the 4th International Meeting of the Society of Avian Paleontology and evolution Washington D. C., 4-7 June 1996: 129-137. Smithsonian Institution Press.

PRICE D. T. \& JACOBS K. 1990. — Olenii ostrov: first radiocarbon dates from major Mesolithic cemetery in Karelia, USSR. Antiquity 64: 849-853.

Price D.T., Ambrose S.H., Bennike P., Heinemeier, J., Noe-Nygaard N., Brinch Petersen E., Vang Petersen P. \& Richard P. 2007. - New information on the Stone Age graves at Dragsholm, Denmark. Acta Archaeologica 78 (2): 183-219.

PRICE N.S. 2001. - An archaeology of altered states: Shamanism and material culture studies in PRICE N.S. (ed.), The Archaeology of Shamanism. Routledge, London and New York: 3-16.

ProKofyeVA Y.E.D. 1963. - The costume of an Enets shaman, in Michael H.N. (ed), Studies in Siberian Shamanism. Anthropology of the North: 124-156. Translations from Russian Sources, No. 4. University of Toronto Press: 124-156.

RAVDONIKAS V. I. 1956. — Neoliticheski mogil'nik na Yuzhnom Olen'em ostrove Onezhskogo ozera. $M a-$ terialy $i$ issledovanija po archeologiji SSSR 47: 7-24. Moskva-Leningrad.

Ryan K. \& Crabtree P.J. (eds) 1995. - The Symbolic Role of Animals in Archaeology. MASCA Research Papers in Science and Archaeology 12: 51-56. Pennsylvania.

SCHANChe A. 2000. - Graver i ur og berg. Samisk gravskikk og religion fra forhistorisk til nyere tid. Davvi Girji OS, Karasjok.

SCHEFFERUS J. 1674/1963. — Lapponia. Translated to Finnish from the original Latin text by Tuomo Itkonen. Arvi A. Karisto Osakeyhtiö, Hämeenlinna.

O'shea J. \& Zvelebil M. 1999. — Oleneostrovski mogilnik: reconstructing the social and economic organization of prehistoric foragers in northern Russia. Journal of Anthropological Archaeology 3, 1-40.

SiIKAlA A.-L. 1981. - Finnish Rock Art, Animalceremonialism and Shamanism. Temenos 17: 81-100.

SiIKALA A.-L. 2002. - Mythic Images and Shamanism. A Perspective on Kalevala Poetry. Suomalainen Tiedeakatemia, Helsinki

Sten S. \& VRETEMARK M. 1988. — Storsgravprojekt- osteologiska analyser av yngre järnålderns benrika brandgravar. Fornvännen 83:145-112.

STJERNQVIST B. 1998. — The basic perception of religious activities at cult-sites such as springs, lakes and rivers in Larsson L. \& Stjernevist B. (eds), The Worldview of Prehistoric Man. Kung.iga Vitterhets Historie och Antikviets Akademien, Stockholm: 157-178.

STOLYAR A.D. 2000. - Spiritual treasures of Ancient Karelia, in Kare A. (ed.), Myandash. Rock Art in the Ancient Arctic. Arctic centre Foundation. Rovaniemi: 136-173

Tilley C. 1991. - Material Culture and Text. The Art of Ambiquity. Routledge, London.

VANPOOL C. 2009. - The Signs of the Sacred: Identifying Shamans Using Archaeological Evidence (2009). Journal of Anthropological Archaeology 28: 170-190.

Von Den Driesch A, Kessler D., Steinmann F. Beretaux V., Peters J. 2005. - Mummified, Deified and Buried at Hermopolis Magna - The Sacred Birds from Tuna el-Gebeh, Middle Egypt. Egypt and Levant 15: 203-244.

WyLIE A. 1985. - The reaction against analogy. Advances in Archaeological Method and Theory 8: 63-111.

Zachos F.E. \& SCHMÖlCKe U. 2006. - Archaeozoological records and distribution history of the osprey (Pandion haliaetus) in Central Europe. Journal of Ornithology 147: 505-568.

ZAGORSKA I. 1997. - Begravningsritual på Zvejniekigravfältet, in ÅKERLUND A., BERGH, S., NORDBLADH J. \& TAFFINDER J. (eds), Till Gunborg-arkeologiska samtal. Stockholm Archaeological Reports Nr. 33: 435-440.

ZAGORSKA I. 2006. - Radiocarbon chronology of the Zvejnieki burials, in LARSSON L. \& ZAGORSKA I. (eds), Back to the Origin. New Research in the MesolithicNeolithic Zvejnieki Cemetery and Environment, northern Latvia. Acta Archaeologica Lundensia Series 8, 52: 91-114.

ZAGORSKA I. \& LOUUGAS L. 2000. - The tooth pendant head-dresses of Zvejnieki cemetery, in LANG V. \& KRIISKA A. (eds), De temporibus antiquissimis ad honorem Lembit Jaanits. Muinasaja teadus 8: 223-244.

ZAGORSKIS F. 1987. - Zvejnieku akmens laikmeta kapulauks. Zinatne. Riga.

ZAGORSKIS F. 2004. - Zvejnieki (Northern Latvia) Stone Age Cemetery. BAR International series 1292. Archaeopress, Oxford.

Zvelebil M. 1997. - Hunter-gatherer ritual landscapes: spatial organisation, social structure and ideology among hunter-gatherers of northern Europe and western Siberia. Analecta praehistoria leidensia 29: 33-50.

Zvelebil M. \& Jordan P. 1999. - Hunter fisher gatherer ritual landscapes - questions of time, space and representation, in Goldhahn, J. (ed) Rock Art as Social Representation. British Archaeological Reports S794, Oxford: 101-127. 